\title{
Çevresel Determinizm Üzerine Karşılaştırmalı Bir Değerlendirme: İbn-i Haldun ve Montesquieu
}

\author{
A Comparative Assessment of Environmental Determinism: Ibn Khaldun and Montesquieu
}

\author{
Sevde Nur KARABİBER \\ Yüksek Lisans Öğrencisi, \\ Kahramanmaraş Sütçü İmam Üniversitesi \\ sevde.karabiber.snk@gmail.com \\ https://orcid.org/0000-0002-2952-4015
}

Makale Başvuru Tarihi: 24.10.2020

Makale Kabul Tarihi: 24.12.2020

Makale Türü: Araştırma Makalesi

\section{ÖZET}

Anahtar

Kelimeler:

Çevresel

determinizm,

İklim,

Beşerî cŏ̆rafya,

Kanun,

Keywords:

Environmental

Determinism,

Climate,

Human Geography,

Law,
Insanlık tarihi boyunca doğal çevre ve insan iç içe olmuştur. Doğa ile etkileşime giren insanlar doğal çevre ve onu oluşturan unsurlardan etkilenmişlerdir. Bu noktada doğal çevre, insanların ve toplumun belirleyicisi hükmündedir. Insan ve toplum belirleyiciliğinde önemli bir yeri olan çevresel determinizm günümüze kadar birçok düşünür tarafindan ele alınmıştır. Bu makalede ise çevresel determinizm çerçevesinde, Ibn Haldun'un, beşerî coğrafyanın birey ve toplum davranışları üzerindeki etkisine dair teorisi ve Montesquieu'nün coğrafya ve buna bağll değişkenlik gösteren yasa koyucuların ortaya koyduğu yasalar ve bunların topluma etkileri üzerine iklim teorisi, çevresel determinizm konusu merkezinde karşılaştırmalı analiz yöntemi kullanılarak iki ana başlık altında ele alınmaya çalışılmıştır. XIV. yüzyılda yaşamış sosyolojinin temelini oluşturan Ibn Haldun Asabiyet ve Umran ilmi teorisi temelinde devletin ve toplumun oluşum sürecini ele almaktadır. XVIII. yüzyıl aydınlanma dönemi düşünürlerinden olan Montesquieu ise bireylerin beraber yaşamalarını sağlayacak yasaların gerekliliğinden bahsetmektedir. Yasanın, toplum düzeni için gerekli olduğundan ve her toplumun kendine ait karakter özellikleri, coğrafyası, ahlakı, yönetim şekli gibi farklılıklardan etkilenerek ortaya çıktı̆̆ını ifade etmektedir. Bu çalışmadaki asıl amaç farklı zamanda ve toplumsal çevrede yaşamalarından hareketle İbn Haldun ve Montesquieu'nun iklimi, siyasal ve toplumsal hayatı ele alış şekillerini yaşamış oldukları dönemsel farklılıklar dikkate alınarak karşılaştırmaktır. Bu karşılaştırma doğal çevre, birey ve toplumsal değerler temelinde ele alınmaktadır. Bu băglamda farklı dönemlerde ele aldıkları çevresel determinizm anlayışının ortak ve varsa farklı yönlerini karşılaştırmak adına "Mukaddime", ve "Kanunların Ruhu” adlı eserler coğrafi bakış açısı ile incelenmiştir. Bu çalışmanın sayıltısı beşerî coğrafyanın kamu düzeninde, toplumda ve yönetimdeki egemenliğinin zaman ve yaşanılan yer fark etmeksizin mutlak surette toplumları etkilemesidir. Bununla birlikte birçok anlayışın temelini oluşturması noktasında önemli bir yere sahiptir

\section{ABSTRACT}

Throughout human history, natural environment and human have been intertwined. People who interact with nature are affected by the natural environment and the elements that make it up. At this point, the natural environment is the determinant of people and society. Environmental determinism, which has an important place in determination of human and society, has been handled by many thinkers until today. In this article, in the framework of environmental determinism, Ibn Khaldun's theory on the impact of human geography on individual and social behavior and Montesquieu's theory of geography and the laws put forward by the legislators that vary accordingly and their effects on society, the climate theory in the center of environmental determinism have been tried to be handled under two main headings by using analysis method. The basis of the theory of Asabiyet and the scientific concepts of Umran, which form the basis of sociology happened in the 19th century deals with the formation process of the state and society basically. Montesquieu, one of the thinkers of the 18th century enlightenment, mentions the necessity of laws that will enable individuals to live together. He states that the law is necessary for the social order and that each society emerges by being affected by differences such as its own characteristic features, geography, morality and management style. The main purpose of this study is to compare the way between how Ibn Khaldun and Montesquieu dealt with the climate, political and social life, taking into account the periodic differences they lived, based on their living in a different time and social environment. This comparison is handled on the basis of natural environment, individual and social values. In this context, in order to compare the common and, if any, different aspects of the understanding of environmental determinism that they dealt with in different periods, the works named "Muqaddime" and "Spirit of Laws" were examined with a geographical perspective. The assumption of this study is that the sovereignty of human geography in the public order, society and administration absolutely affects societies regardless of time and place of residence. However, it has an important place in forming the basis of many understandings. 


\section{GİRIŞ}

İnsanlar dünyaya geldiklerinden itibaren doğayla iç içe olmuşlardır. İnsanların doğa ile olan bu ilişkisi birçok bakımdan doğaya bağımlı olmalarından kaynaklanmaktadır. Bu durumun nihai sonucu olarak da insan ve insan toplulukları doğa şartlarından olumlu ve olumsuz olarak etkilenmektedir. İnsanların doğa ile olan ilişkileri; ekonomik, siyasi, sosyal ve kültürel alanları dünyaya geldiklerinden itibaren etkilediği birçok bilim insanı tarafindan ortaya koyulmuştur. Böylece insanların içinde yaşadığı çevre, bireylerin birbirleriyle etkileşime girdikleri süreç içerisinde kültürel, sosyal ve siyasi anlamda gelișmekte ve değișmektedir. Gelișim ve değișimin bir sonucu olarak da insanların doğa ile olan ilişkisi onların birtakım özelliklerini ve karakterini etkilemektedir. $\mathrm{Bu}$ özellikler, insanların içinde yaşadıkları çevrenin, iklim yapısının ve yeryüzü şekillerinin etkisi ile birtakım değişikliklere uğramaktadır. Nitekim mevcut iklim yapısı ve yeryüzü şekilleri bireylerin ahlak, huy, karakter ve genetik özelliklerini etkilemektedir. Bu varsayım doğa ve insan ilişkisini, insan topluluklarının sosyal ve kültürel oluşumunu etkileyen bir faktör olduğunu ortaya koymaktadır. Çevresel determinizm denilen bu olguda "çevre, insan özellikleri üzerinde belirleyici olduğu gibi insan da çevreyi etkilemektedir" görüşü hakimdir. Doğal olarak oluşturulmuş ve insanlar yoluyla karşılıklı belirleyiciliği olan çevre, coğrafi bakış açısıyla ele alınmaktadır. Çevresel determinizmi ele aldığımız bu çalışmayı daha iyi anlamak için öncelikle çevresel determinizmin temellerini oluşturan kavramları anlamamız gerekir.

Çevresel determinizmi oluşturan çevre kavramı, canlıların birbirleriyle etkileşim halinde bulundukları birbirlerini etkiledikleri ve birbirlerinden etkilendikleri alan olarak tanımlanabilir (https://tr.wikipedia.org/wiki/Doğal_Çevre). Determinizm veya diğer adıyla belirlenimlilik kavramı ise belirli olayların birtakım düzene bağlı olarak gerçekleştiğini ve bu düzenden yola çıkarak elde edilecek sonuçların önceden tahmin edilebilmesi durumu olarak aç1klanabilmektedir (https://tr.wikipedia.org/wiki/Determinizm). Bu tanımlar çerçevesinde çevresel determinizm konusu temele alınarak doğanın insan üzerindeki etkileri yapılan çalışmalarda birçok tezin ortaya çıkmasına sebep olmuştur. Bu noktada doğayı inceleme konusu yapan coğrafya alanı bize doğal bir süreçte öngörülebilir çıkarımlar yapmayı sağlar.

Çalışmamızı daha iyi açıklayabilmek adına coğrafyanın inceleme alanı olan beşerî ve fizikî coğrafyadan bahsedilmelidir. Fizikî coğrafya kapsamı içerisine bitki ve hayvan yaşamı, yeryüzü şekilleri, denizler, iklim ve bitki örtüsü gibi konular yer almaktadır. Fizikî coğrafyanın kapsamındaki alt dallarda jeoloji, jeomorfoloji, klimatoloji, biyoloji vb. yer almaktadır. Beşerî coğrafyanın kapsamında insan ve insana dair olgular ön planda olmasından dolayı fizikî coğrafyadan ayrılmaktadır. Beşerî coğrafya, doğal çevrenin insanların üzerindeki etkisini ve yaşadığı çevre üzerindeki faaliyetlerini incelemektedir. Beşerî coğrafyanın kapsamındaki alt dallarda sosyoloji, siyaset, tarih, ekonomi ve demografi yer alır. Çalışmamızda hem fizikî coğrafyayı hem de beşerî coğrafyayı ortak bileşenleriyle birlikte ele alacağız ki zaten birbirinden bağımsız olarak düşünmek olanaksızdır. Bu iki yaklaşımı ortak payda da birleştiren "bölgesel coğrafya"dır. Bölgesel coğrafya, insanların karşılıklı olarak etkileşime girdikleri yaşam alanını incelemektedir. Bu etkileşim fizikî ve beşerî coğrafya ekseninde birçok bakımdan toplumların farklılaştığını ortaya koymaktadır. Bu farklılaşmayı ortaya koyarken de özellikleri bakımından yeryüzü belli bölgelere ayrılmaktadır. Determinist bakış açısının etkisiyle bu bölgeler çevresel şartlar göz önüne alınarak belirlenmiştir (Tümertekin ve Özgüç, 2015:41-66).

Esas itibariyle bu çalışmanın içeriğini çevrenin insan üzerindeki belirleyici rolünü konu alan çevresel determinizm oluşturmaktadır. İklimin, yeryüzü şekillerinin ve doğal koşulların toplumsal yaşam biçimleri, sosyal ilişkiler, hukuk kuralları ve insanların karakteristik özellikleri üzerindeki etkileri ele alınmıştır. Bu çalışmada üzerinde durulan konu bütün yönleriyle ele alınmamış, temel konu coğrafi bir bakış açısı ile toplumsal değerler üzerindeki değişimler çerçevesinde ele alınmaya çalışılımıştır. Çevresel determizme sosyolojik, tarihi, coğrafik ve biyolojik bir bakış açısıyla yaklaşılmaktadır. Bu çalışmada çevresel determinizm ekseninde farklı perspektiflere sahip düşünceler ele alınmıştır. Determinist bakış açısı kendisinden sonra ki dönemlerde ortaya çıkan teorilere kaynaklık etme konusunda önemli bir yere sahip olmuştur. Çevresel determinizm insan ve çevre ilişkisini açıklamada ilk basamak olmasından hareketle önem arz etmektedir. $\mathrm{Bu}$ bağlamda çevresel determinizm olgusu çerçevesinde İbn Haldun'un Kitab'ul İber kitabının iki ciltlik Mukaddimesi ve Montesquieu'nun Kanunların Ruhu Üzerine kitabı karşılaştırmalı analiz yöntemi ile ele alınmıştır. Bu çalışma ile alakalı veri analizi sırasında literatür tararken Maxqda programından faydalanılmıştır. Analizler iki defa yapılarak güvenirliğin arttırılması amaçlanmıştır. Nesnel verilere ulaşmamızı ve bu verileri özetleyerek anlamlı sonuçlar sunmamızı sağlayan içerik analizi yöntemi kullanılmıştır.

Bu çalışmanın sınırlılığı ise çevresel determinizmle ilgili Türkiye'de yeterince yerli kaynağın bulunmaması ve determinizmden sonra gelişen birçok anlayış karşısında bu görüşün yetersiz kalmasıdır. Bu doğrultuda 
çalışmada doğrudan ve dolaylı bir şekilde doğal çevrenin etkisinde olan insan üzerinde durulmaktadır. Ayrıca incelenen birçok makale ve tezin büyük çoğunluğunun kitaplardan çok, yazılan makalelere atıf yapması bu gerçeği ortaya koyuyor.

\section{BİR CALIȘMA ALANI OLARAK ÇEVRESEL DETERMİNIZM}

Coğrafyanın ve içinde barındırdığı unsurların modern anlamda bilimsel bir alan oluşturmasında Kant, Humboldt, Ritter, Darwin ve Ratzel'in incelemeleri etkili olmuştur. Bu dönemde coğrafyaya olan ilgi artmış, bölgesel coğrafyanın mevcut araştırma konularına dâhil olmasıyla birlikte bilim dünyası ilerleme kaydetmiştir. Ortaya koyulan bilimsel eserler fiziki coğrafya ekseninde ele alınmıştır (Özgüç ve Tümertekin, 2000'den akt.: Özgen ve Karadoğan, 2016:21).

Filozof olan Kant, yaşadığı dünyayı yönetim şekilleri ve fizikî coğrafya açısından ele alıyordu. Ona göre yaşam içerisindeki süreç kronolojik olarak ifade edilmeliydi. Bu bakımdan tarih ve coğrafyayı birlikte ele almaktadır. Doğal koşulların zamansal ve mekânsal farklılıklarından bahsetmektedir. Felsefeye olan ilgisi fikirlerinin teoride kalmasını sağlamıştır. Uygulamaya geçirenler eski coğrafya ile modern coğrafya arasında bir bağ oluşturan Humboldt ve Ritter'dır. Humboldt çalışmalarını 1793 yılında yayınlamaya başladı. Çalışmalarında yaptığı birçok gezinin faydası olmuştur. Gezileri esnasında tuttuğu noktalar ve aynı dönemde yaşadığı birçok bilim insanı araştırmalarında etkili olmuştur. Bilimsel çıkarımların deneyim ile elde edileceği fikrini ampirik bir bakış açısıyla ortaya koymaktadır. Humboldt doğayı daha çok ekolojik yönden ele alır ve insanın doğal sistemin bir parçası olduğunu ifade eder. Ritter ise bölgesel coğrafya ve tarihsel süreç etrafinda konuyu ele alır. İkisi de doğal çevreyi incelerken karşılaştırmalı analiz yöntemini kullanır. Ritter, tarih ve coğrafyanın ayrılmaz bir bütün olduğunu ifade ederken doğal çevrede ortaya çıkan olayların birbiriyle ilişkili olduğunu ortaya koymuştur. İnsanların mekanlardaki ilişkileri açısından nasıl örgütlendikleri ve mekânı nasıl kullandıklarını hakkında çalışmalar yapmıştır (Tümertekin ve Özgüç, 2015:14-23). Humboldt ve Ritter sonrası dönemde Darwin, Türlerin Kökeni adlı kitabını yayınlar. Çevresel determinizmin ilk kuramsal temellerini oluşturan ve bu konuyu biyolojik, kalıtsal ve genetik özellikler çerçevesinde ele alan Darwin'dir. Evrim kuramı ve sosyal darwinizm, çevresel determinist düşüncenin ortaya çıkması noktasında belirleyici olmuştur. $O$ dönemde coğrafyacılar, Darwin'in teorilerinden yola çıkarak insanın ve yaşadığı mekânın belli süreçler sonucunda evrim geçirdiğini ifade etmişlerdir.

Bu durum Darwin'in coğrafyacı olduğu anlamına gelmez ama ortaya koyduğu teori ile birçok coğrafyacıyı ve sosyoloğu etkilemiştir. Doğal seçim teorisi ile insan ve çevre ilişkisine dair teorilerin ortaya çıkmasını sağlamıştır. Bu teoriler insanların yaşadığı fiziki çevrenin sürekli bir değişim içinde olduğunu ve bu değişimin o çevrede yaşayan insanların da birtakım özelliklerinin değişmesinde etkili olduğunu ortaya konmuştur (Tümertekin ve Özgüç, 2015:23).

Darwin canlıların hayatta kalmaları için içinde bulundukları ortama uyum sağlamaları gerektiği üzerinde durmuş̧tur. Canlıların uyum sağlamaya çalıştıkları ortamda verdikleri yaşam mücadelesi sonucu birtakım özelliklerinin gelecek nesillere aktarılabildiğinden bahsetmektedir. Darwin'in "doğal seçme" adını verdiği bu teori mevcut ortama uyum sağlayamayan canlıların yok olmaya mahkûm olduğunu, uyum sağlayabilen canlıların ise yaşama şanslarının yüksek olduğunu ortaya koymaktadır (Darwin, 2013:99-100).

Ortama uyum sağlayan canlılar gelecek nesillere bu özellikleri genetik olarak aktarabilmektedir. Canlıların aktarmış olduğu özellikler bulundukları ortamlara daha rahat uyum sağlamaları sonucunu ortaya koymaktadır. Yaşadıkları bölgedeki iklime bağlı olarak mevcut ortama uyum sağlayan canlılar kendi içerisinde farklılıklar göstermektedir (Darwin, 2013:65-66). Hayvanlarda olduğu gibi insanların da tek bir türden gelmediğini sürekli bir değişim geçirdiğini ortaya koymuştur. Bu değişimin nedenleri arasında iklim, beslenme şekli, fiziki koşullar gibi birçok faktörü saymak mümkündür (Darwin, 2013:27-28). Darwin'in ortaya koyduğu teorinin temeli canlıların üzerinde belirleyici olan çevresel ve biyolojik özelliklerdir. Bu yüzden Darwin'in biyolojik determinizm ve çevresel determinizm ağırlıklı görüşler ortaya koyduğu görülmektedir.

Friedrich Ratzel Darwin'in teorisinden zooloji alanında doktora yaptığı sırada etkilenmiştir. İnsanın fiziki çevreye uyum sağlayabildiği sürece doğal koşullar karşısındaki güçlükleri kolaylıkla aşabileceği düşüncesini ortaya koymuştur. Ratzel'in düşünceleri kısa bir süre içerisinde Avrupalı pek çok bilim insanı arasında yayılıp, kabul görmeye başlamıştır. Bu bilim insanlarından biri olan Semple, Ratzel'in öğrencisi olup onun fikirlerinden etkilenmiştir. Çevresel determinizmin Amerika'da yayılmasında ciddi bir payı olmuştur. Çevreyi ele alırken insanı hükmü olmayan bir varlık olarak ele almamıştır. İnsan ve çevre ilişkisinde doğal koşullar açısından mevcut durumu değerlendirmenin insan üzerindeki yansımalarına değinmiştir. Çevrenin insan üzerindeki 
etkililiği noktasında kaleme aldığı yazılarıyla o dönemde birçok öğrenciyi de etkilemiştir (Tümertekin ve Özgüç, 2015:23-25).

J. Diamond ise Darwin'in biyolojik determinizminden olabildiğince uzak kalmaya çalışsa da, genel itibariyle çevresel determinizm odaklı incelemeler yapmaktadır. Çevresel determinizmi toplumların gelişmişlik düzeyi kapsamında ele almaktadır. Diamond'a göre çevresel koşullar insanların yaşam şekillerine ne kadar elverişli olursa, o toplumun gelişmişlik düzeyi de o denli artış gösterecektir (Diamond, 2010:24) Bunun sonucu olarak bireylerin bulundukları çevre şartlarına uyum sağlayabilmeleri için yaratıcı çözümler bulmaları gerektiğini ortaya koymaktadır. Zor çevre şartlarına sahip toplumlar yaratıcılık özelliğine sahip olan ve bu durumun sonucu olarak da gelişme ve değişme gösteren toplumlardır. Bu noktada Diamond gelişim gösteren toplulukları, sahip oldukları imkânları en iyi şekilde kullanabilen ve değerlendirebilen topluluklar olarak tanımlamaktadır (Diamond, 2010:24).

Kutluer çevresel determinizmi, doğal çevrenin insanların davranış ve kültürünü etkilediği ve var olan nedenlerin doğal bir sonucu ortaya çıkarması durumu olarak açıklar. Ona göre bu durum olması gereken doğal bir süreçtir (Kutluer, 1994:215). Toparlayacak olursak çevresel determinist bakış açısı toplumun ahlaki, fiziki ve kültürel yapısının çevrenin etkisi sayesinde belirli kalıplar içinde yer aldığını ve benzer çevre koşullarının benzer insan yapısını oluşturduğu görüşünü ortaya koyar.

Çevre ve insan ilişkisi çeşitli yönlerde ele alınmaktadır. Bu ilişkiyi sosyolojinin temellerini atan İbn Haldun, coğrafi koşullar ve toplum açısından ele almaktadır. Burada öncelikle iklimin, soy bağının ve yaşanan kültürün insan, karakter ve davranışlarına ne gibi farklılıklar kattığından ve bu farklılıkların sonuçlarından bahsedilmektedir. İbn Haldun aynı zamanda Montesquieu ile birçok bakımdan benzerlik gösterdiği için İslam'ın Montesquieusü olarak anılmaktadır (İbn Haldun, 2011:119). Montesquieu iklim koşullarının, İbn Haldun'un görüşlerindeki gibi insanı birçok bakımdan etkilediğinden bahsetmektedir. Ayrıca farklı iklim bölgelerindeki insanların farklı karakter yapılarının olduğundan bahsetmiştir. Farklı iklim yapısının oluşturmuş olduğu farklı insan karakterlerine uygun şekilde yönetilmeleri gerektiği üzerine durmuştur. Kanunların insan niteliklere uygun bir şekilde oluşturulması gerektiğini ortaya koymuştur (Montesquieu, 1998:321). Çevrenin insan üzerindeki etkisini coğrafik bakımdan ele alan İbn Haldun ve bu ilişkiyi hem hukuk hem de yönetim açısından ele alan Montesquieu'nun coğrafi olgulara karşı bakış açıları ele aldıkları temel konuları etkilemesi noktasında birbirleriyle benzerlik göstermektedirler.

Ayrıca çevresel determinizmle birlikte ortaya çıkan görüşlere karşılık Acemoğlu ve Robinson (2013) farklı bir bakış açısıyla konuyu tekrar ele almışlardır. Aynı fiziki şartlara sahip ülkeler arasında çevre dışındaki faktörlerin etkilerinden dolayı gelişmişliklerinin de farklılıklar gösterdiğini ortaya koymuştur. Toplumun gelişim ve değişiminde ekonomik, sosyal ve siyasal faktörlerin de rol oynadığını çevresel faktörlerin tek başına bir toplumun gelişmişliğine etki etmediğini ifade etmiştir (Arı, 2017:6). Bu açidan toplumsal ilişkiler, kültürler, gelenekler, yönetim şekilleri, kanunlar ve yaşam biçimleri gibi durumlar temelde çevresel faktörlerden etkilendiği gibi buna birçok beşeri faktörü de eklemek mümkündür.

\section{3. ÇEVRESEL DETERMINIZME BAKIŞ}

Çevresel determinizm olgusu birçok araştırmacı tarafından farklı perspektiflerde ele alınmıştır. Bir tarih bilimci ve devlet adamı olan İbn Haldun XIV. yüzyılda yaşadığı toplumu ve devlet idaresinde bulunduğu yönetimler doğrultusunda yaşadığı toplumdan farklı bir bakış açısı ortaya koyarak çalışmalar yapmıştır. Yaptığı çalışmalar kendisinden sonra birçok araştırmacıyı etkilemiştir. Ortaya koyduğu teoriler kapsamında kendisinden 357 yıl sonra bir hukukçu olan Montesquieu toplum ve yönetime dair benzer teoriler ortaya koymuştur. Farklı yaşam tarzlarına ve toplumsal olgulara sahip olmaları Montesquieu'nun oryantalist bir bakış açıya sahip olmasına da neden olmuştur. Bu noktada aralarındaki benzerlik ve farklılık ilişkilerini ele almak Kuzey Afrika ülkelerini ve Avrupa ülkelerini inceleme noktasında önem arz etmektedir.

\section{1. İbn Haldun'a Göre Çevresel Determinizm}

27 Mayıs 1332 tarihinde Tunus'ta doğan İbn Haldun'un asıl adı Abdurrahman bin Muhammed bin Ebubekir bin Hasan'dır. İbn Haldun'un büyük dedesi Halit bin Osman İspanya'ya yerleşmiş o bölgede ün salmış bir siyaset adamıdır. İsminin Haldun olmasını sağlayan neden ise dönemin Endülüs adetlerine uyum sağlamak amaciyla ismine ' $u$ ' ve ' $n$ ' harflerini eklemesidir. Ailesi sonraları ata toprağı olan Tunus'a göç etmiştir. Soylu bir aileden gelen İbn Haldun'un ailesinde çok sayıda yönetici ve bilim insanı vardır. Bu durum İbn Haldun'un kariyerinde 
önemli bir gelişme sağlamıştır. Dönemin en donanımlı âlimlerinden eğitim almasını sağlayan ve ilk eğitimini veren babası Muhammed'dir. İbn Haldun yaşadığı önemdeki âlimlerden farklı bir bakış açısına sahipti. Dönemin âlimleri siyaseti kötü bir iş olarak görüyorlardı. O ise siyasetin içinde devleti ve dönemin devlet erkânını yakından incelemeyi tercih etmiştir. Çalışmalarını Tunus, Cezayir, Fas, Endülüs (İspanya), Mısır ve Şam'da sürdürdü. Bu ülkelerde birç̧ok siyasetçi ve bilim adamıyla sohbetler etti. Büyük kütüphanelerinden faydalandı. Devlet mekanizması içindeki diplomatik görevlerinde ciddi deneyimler kazanmıştır. Bu deneyimlerini ilk olarak Kitab'ul İber eserinde okuyucuya sunmuştur (İbn Haldun, 2004:13-18). Dünya tarihi anlatılan 7 ciltlik bu eserin giriş kısmını en önemli eseri olan Mukaddime oluşturmaktadır. Modern tarihin ve coğrafyanın öncülerinden biri olan İbn Haldun yaptığı toplumsal tespitlerle birçok bilim insanına fayda sağlarken pek çok teorinin zeminini oluşturacak fikirler ortaya koymuştur.

Genel olarak İbn Haldun'un az gelişmiş ülkelerin evrimine dair görüşler ortaya koyduğu ifade edilmektedir. Bu düşünce tam anlamıyla yanıltıcı ve yanlıştır. İbn Haldun 14. yüzyıl ortaçağ topluluklarını tasvir etmeye çalışmıştır (Lacoste, 2012:8). Bu toplulukların özelliklerini ifade etmeden önce İbn Haldun açısından "umran" ilmi üzerinde durmak gerekir. Umran ilmi; doğanın bir yerde oluşturduğu yönetsel, kültürel ve toplumsal uğraşların tümüdür. Bu uğraşlar topluluk halinde yaşayan bireylerin birbirlerine karşı üstünlük göstermelerini sağlar (Lacoste, 2012:109).

İbn Haldun, toplumdaki bireylerin birbirleri üzerindeki üstünlüklerine "asabiyet" kuramında değinmektedir. Buna bağlı olarak asabiyetin yalnızca Kuzey Afrika bölgesi için söz konusu olduğunu da belirtmektedir (Lacoste, 2012:122). Bu kuramda bahsedilen asıl mesele birçok kavmin bulunduğu bir yerde tüm kavimleri birleştirecek ve yönetecek tek bir kavmin olduğudur. Yönetme vazifesini elinde bulunduran bu kavmin de güçlü bir soy bağına sahip olması gerekmektedir. Burada soy bağı, önceki nesillerin genetik özelliklerinin sonraki nesillere geçmesi olarak ifade edilirken bireyler arasındaki toplumsal dayanışmayı sağlayan en önemli etken olarak da tanımlanmaktadır (Lacoste, 2012:115).

Asabiyet kuramında, bir toplumda güçlü bir soy bağının olması toplu halde yaşayanların yönetiminin devamlılığı açısından önemlidir. Soy bağı olarak adlandırılan durum aslında çevrenin insan üzerindeki 3 etkisinden biridir. Bu etkilerden ilki olan nesep yani soy bağı insanların birtakım özelliklerinin genetik olarak aktarılabileceğini savunur. Diğer etken ise mevcut durumda yaşanılan coğrafi bölge ve iklim şartlarının insanlar üzerindeki ortak yansımalarıdır. Sıcak, soğuk ve 1lıman iklim bölgelerinden bahsedilmektedir. Bu bölgelerden birinde yaşayan bireylerin özellikleri iklim bölgeleri aynı olan diğer bireylerle birbirine çok yakındır. Fakat farklı bölgelerin toplumları iklim, yeryüzü şekilleri, kuşak farkları gibi özelliklerden dolayı farklılık gösterdiği ortaya koyulmaktadır. İnsanların mevcut birçok durumuna etki eden son özellik ise İbn Haldun'un ictimaî itiyat olarak ele aldığ 1 gelenek ve göreneklerdir. Bu görüş ile birlikte İbn Haldun milletlerin ve toplumların tüm özelliklerinin, yeteneklerinin ve huylarının tamamen soy bağından gelmediğini ifade eder. Bazı milli değerlerin, alışkanlıkların ve birtakım yeteneklerin ırka bağlı olmadığını ortaya koymuştur. Bu noktada bu yetenekleri, meziyetleri ve değerleri elde etmek, toplumun bunları kazanma kabiliyetine ve fiziki şartlara bağlıdır (İbn Haldun, 2011:264).

Asabiyet kuramını daha çok devlet yönetimi içerisinde görmekteyiz. Topluma hükmetme asabiyeti oluşturan kesimlerce paylaşılmıştır. Ülke içindeki bu üstünlük mücadelesi devleti ve yönetimi de diri tutmaktadır. Yalnız bir otoritenin mevcudiyeti toplumu elindekilere razı olmaya iter güç dengeleri bozuldukça asabiyet de bozulur ve devlet zayıflama sürecine girer. Devleti zayıflama sürecine sokan diğer bir etken otoriteyi elinde bulunduran kesimin topluma baskı uygulamasıdır. Devletin daimî olması için iktidar mücadelelerin olması gerekir. Devlet olmanın diğer bir sunucu da sosyal refahtır. Rahat yaşam zamanla alışkanlık olmaya başlar sonrasında karakter haline gelir. Böylece bedevilik adetlerinden ve yaşam tarzından uzaklaşmaya başlanmış olur (İbn Haldun, 2004:238-239). Sosyal refah ve zenginlikle beraber şehirleşmeye başlanmıştır. Bu durum İbn Haldun'un "Medeniyetleşme" dediği bedevi hayattan şehir hayatına geçilen evredir. Bolluk ve zenginlik, medenileşmeyi sağladığı gibi ortaya çıkardığı birtakım aşırılıklar devleti çöküş sürecine sokmaktadır. Çöküş evresine gelen devletleri İbn Haldun şöyle çözümler:

Otoriteyi elinde bulunduran yönetim baskıcı uygulamalarıyla kamu düzenine ciddi zarar verir. Refah sağlama uğruna alınan ağır vergiler halkı zor duruma sokar ve daha çok çalışarak daha çok kazanma duygusunun önüne geçer. Bu durumun zorunlu bir sonucu olarak sosyal hayat zarar görür ve devlet yıkılma sürecine girer (Lacoste, 2012:99-100). Özetle toplumsal düzenin bozulması devlet düzeninin bozulmasına yol açmaktadır. Bu düzeni sağlamak toplumsal ilişkileri sağlam bir zemine oturtarak mümkün olacaktır.

Dünya belirli bir düzen içerisinde yaratılmıştır. Bu düzeni oluşturan en önemli faktör insandır. Bu düzenin bir parçası olan insanı şekillendiren, etkileyen birçok olgunun başında yaşadığı toplum gelmektedir. Bu yüzden 
insanın en önemli belirleyicisi yaşadığı toplumdur. İnsan bulunduğu toplumu etkiler ve bu toplumdan etkilenir (Şeriâti, 2017:74-77). Toplumun da en önemli belirleyicilerinden biri çevre ve bu çevrede yaşanan iklim şartlarıdır. Bir bitki nasıl ki her bölgede yetişmiyor ve çevreye uyum sağlamaya çalışıyorsa bir toplum da yaşadığı çevre şartlarına uyum göstermekte ve diğer çevre şartlarına sahip bireylerden farklı özellikler ortaya koymaktadır. Çevrenin insan üzerindeki etkisinden bahsederken coğrafi bölgelerin belirleyicilik açısından ciddi bir payının olduğunu söylemek mümkündür.

\subsection{1. İbn Haldun'un Bölgesel İklim Teorisi}

Batlamyus, yerküreyi iklim şartlarına göre yedi ana bölgeye ayırmıştır. 14. Yüzyılda Batlamyus Coğrafya Okulu'nda eğitimine devam eden İbn Haldun da Batlamyus'un yedi iklim kuramını temele alarak çevresel koşulların insan üzerindeki etkilerine değinmiştir. Yedi iklim bölgesinden birinci bölgeyi en güney nokta alır. Burası aşırı sıcak iklimin hâkim olduğu bölgedir. Yedinci bölge olarak da en kuzeydeki noktayı kabul eder. Burada en soğuk bölge olan kuzey paraleli (yedinci iklim bölgesi) ve en sicak bölge olan güney paralelinden (birinci iklim bölgesi) iç kesimlere doğru gidildikçe iklim şartları daha ölçülü bir hal alarak 1lıman iklim şartları yaşanır (İbn Haldun, 2011:259).

Tablo 1: İbn Haldun'un yedi iklim bölgesi

\begin{tabular}{|c|c|c|c|}
\hline İKLİMLER & BÖLGELER & $\begin{array}{l}\text { BÖLGELERIN HAVA } \\
\text { KOŞULLARI }\end{array}$ & BÖLGELERİN DAĞILIŞI \\
\hline \multirow{2}{*}{$\begin{array}{l}\text { SICAK } \\
\text { İKLIMLER }\end{array}$} & 1.Kuşak & Aşırı sıcak hava koşulu & $\begin{array}{c}\text { Gana, Sudan'ın güneyi, Habeş ülkeleri, Arabistan Yarımadası, Yemen, } \\
\text { Çin }\end{array}$ \\
\hline & 2.Kuşak & Sicak hava koşulu & $\begin{array}{c}\text { Gana'nın kuzeyi, Nijer Sahrası, Kızıldeniz, Fars Denizi, Hicaz, Hint } \\
\text { Denizi, Çin'in Saygon şehri }\end{array}$ \\
\hline \multirow{3}{*}{$\begin{array}{l}\text { MUTEDİL } \\
\text { (ILIMAN) } \\
\text { İKLİMLER }\end{array}$} & 3.Kuşak & $\begin{array}{l}\text { 2. ve 4. Kuşak arasinda } \\
\text { sicak hava koşulu }\end{array}$ & $\begin{array}{c}\text { Kuzey Afrika, Akdeniz, Şam, Cezayir, Mısır, Ceyhun Nehri, Türk ve } \\
\text { Tibet bölgeleri, Çin'in kalanı }\end{array}$ \\
\hline & 4.Kuşak & $\begin{array}{c}\text { En mutedil (1lıman) } \\
\text { hava koşulu }\end{array}$ & $\begin{array}{c}\text { Akdeniz, Endülüs, Malta Adaları, İtalya, Suriye, Mezopotamya, Hazar } \\
\text { Denizi, Semerkant ve Buhara, Yecüc ve Mecüc Dağ1 }\end{array}$ \\
\hline & 5.Kuşak & $\begin{array}{l}\text { 4. ve } 5 \text {. Kuşak arasında } \\
\text { sıcak hava koşulu }\end{array}$ & $\begin{array}{c}\text { Endülüs’ün kuzeyi, Alp Dağları, Venedik Körfezi, Ege ve Marmara } \\
\text { Denizi, Türk İlleri, Anadolu, Ermeni bölgesi, Yecüc ve Mecüc bölgesinin } \\
\text { bir kısmı }\end{array}$ \\
\hline \multirow{2}{*}{$\begin{array}{l}\text { SOĞUK } \\
\text { İKLIMLER }\end{array}$} & 6.Kuşak & Soğuk hava koşulu & $\begin{array}{c}\text { Britanya toprakları, Fransa, Almanya, İstanbul, Hazar toprakları, Türk } \\
\text { kavimleri, Yecüc ve Mecüc bölgesi }\end{array}$ \\
\hline & 7.Kuşak & Aşırı soğuk hava koşulu & $\begin{array}{c}\text { İngiltere, Rusya, Polonya, Türk boyları (Kımazek,Tatar, Peçenek), Yecüc } \\
\text { ve Mecüc Seddi }\end{array}$ \\
\hline
\end{tabular}

Kaynak: İbn Haldun, 2004:90-115

İbn Haldun'un yedi coğrafi bölgeye ayırdığı kuşakların iklim özellikleri ve bölgesel dağılış şekilleri şunlardır:

Birinci iklim bölgesinde aşırı sıcak hava koşulları mevcuttur. Bu iklim; Gana, Sudan'ın güneyi, Habeş ülkeleri, Arabistan Yarımadası, Yemen, Çin'de görülmektedir. İkinci iklim bölgesinde sıcak hava şartları hâkimdir. Bu iklim; Gana'nın kuzeyi, Nijer Sahrası, Kızıldeniz, Fars Denizi, Hicaz, Hint Denizi, Çin'in Saygon şehrinde görülmektedir. Üçüncü iklim bölgesinde ikinci bölge ve 1lımana yakın bir hava koşulu görülmektedir. Bu iklim; Kuzey Afrika, Akdeniz, Şam, Cezayir, Mısır, Ceyhun Nehri, Türk ve Tibet bölgeleri, Çin'in kalanında görülmektedir. Dördüncü iklim bölgesinde 1lıman bir hava hâkimdir. Bu iklim; Akdeniz, Endülüs, Malta Adaları, İtalya, Suriye, Mezopotamya, Hazar Denizi, Semerkant ve Buhara, Yecüc ve Mecüc Dağı çevresinde görülmektedir. Beşinci iklim bölgesinde altıncı bölge ve 1lımana yakın bir hava koşulu görülmektedir. Bu iklim; Endülüs'ün kuzeyi, Alp Dağları, Venedik Körfezi, Ege ve Marmara Denizi, Türk İlleri, Anadolu, Ermeni bölgesi, Yecüc ve Mecüc bölgesinin bir kısmında görülmektedir. Altıncı iklim bölgesinde soğuk hava koşulu hakimdir. Bu iklim; Britanya toprakları, Fransa, Almanya, İstanbul, Hazar toprakları, Türk kavimleri, Yecüc ve Mecüc bölgesinde görülmektedir. Yedinci iklim bölgesi aşırı soğuk hava koşulunun hâkim olduğu bölgedir. Bu iklim; İngiltere, Rusya, Polonya, Türk boyları (Kımazek, Tatar, Peçenek), Yecüc ve Mecüc bölgesinde görülmektedir (Tablo1).

En ideal yaşam alanı olarak ifade edilen 4. İklim bölgesi, dönencelerde bulunan 3. İklim bölgesi ve 5. İklim bölgesinin hava şartlarına göre daha 1lıman ve ölçülü bir yapıya sahiptir. Bu bölgelerde yaşayan insanlar da iklimden etkilenmektedirler. Etkilendikleri bu iklim yapısı da insanların yaşayışşsekillerine yansımaktadır (İbn Haldun, 2011:260). İklim şartları 1lıman bölgelerde yaşayan toplulukların aşırılıklardan ve bazı sapmalardan uzak kalmalarını sağlamıştır. Genel itibariyle birinci ve ikinci iklim bölgesindeki topluluklar güneşi günde iki defa dik açıyla almalarından dolayı bölgeye aşırı sıcaklar bastırır. Bu aşırı sıcaklar neticesinde ise o bölgede yaşayan insanların derileri bronzlaşır ve kararır. Yine mizaç yönünden birinci ve ikinci iklim bölgesindeki 
insanlara benzeyen altıncı ve yedinci iklim bölgelerinde yaşayan insanların tenleri beyazdır. Kuzey bölgesinin çok soğuk olmasından kaynaklı, havanın mizacı ve özelliği insanları etkilemektedir. Bu durumun sonucu olarak bu bölgenin insanları beyaz tenli, mavi gözlü, sarı ve kızıl saçlıdır (İbn Haldun, 2011:262). İbn Haldun bu özelliklerin iklim koşullarına göre değiştiğini ortaya koymaktadır.

Fiziki şartlarla birlikte havanın ve iklimin de insan ahlakı üzerinde birtakım etkisinden söz edilmektedir. Bu etkilerden bahsederken ilk olarak sıcak iklimdeki topluluklar ele alınmaktadır. Sicak iklimde bulunan Sudanlılar ve zenciler genel olarak tez canlılıklarıyla, zevk ve sefaya düşkünlükleriyle bilinirler. Eğlenceye düşkünlüklerinden dolayı da ahmak olarak bilinirler. Bu durumun sonucu olarak zevke düşkünlükleri sicak iklim topluluklarında hayvani ruhun yayılması durumunu ortaya çıkarmıştır (İbn Haldun, 2011:266).

Sıcak iklimde yaşayan toplulukların zevk ve sefaya düşkünlüğü soğuk bölgelerde yaşayanlar için daha farklı bir hal almıştır. Bu ruh hali sıcak iklim topluluklarında ferahlık, kararsızlık ve acelecilik sağladığından dolayı olayların sonuçlarının ne olacağına dair fikir yürütmeleri de zorlaşır. Bu noktada Galenus ve Kindî ise sıcak bölgelerdeki insanların beyinlerinin gelişmediğini buna bağlı olarak zihinsel faaliyetlerinin az olduğunu ifade eder. Bu bölgedeki insanların beyinlerinin gelişememesi sonucunda akıllarının ve düşünme kabiliyetlerinin azaldığını ortaya koymaktadırlar (İbn Haldun, 2011:267). Bu düşüncelerden bir diğeri Ensâb âlimleri tarafindan ortaya atılan bir fikir olan birinci ve ikinci iklim bölgelerindeki siyahilerin Hz. Nuh'a karşı oğlu Hâm'ın işlemiş olduğu günahtan dolayı tenlerinin karardığı gibi asılsız bir iddia ortaya koymuşlardır. Aynı zamanda bu âlimler kuzeydeki halkın tümünün ya da büyük çoğunluğunun Hz. Nuh'un oğlu Yafes'in soyundan geldiğini kabul ederler. Orta kuşakta yaşayan 1lımlı milletlerin çoğunun ise Hz. Nuh'un diğer bir oğlu olan Sâm'ın neslinden geldiği kabul edilmektedir. Orta Çağda bilimsel temellerden uzak bu gibi birtakım asılsız fikirler ortaya konulmuştur. Bu tezlerini herhangi bir delile dayandırmadıklarından dolayı İbn Haldun tarafından geçerliliği kabul görmemiştir (İbn Haldun, 2011:263).

Soğuk iklim şartlarında yaşayanlar ise daha ciddiyet sahibi, hüzünlü bir hâl üzere ve sorumluluklarının farkında olan topluluklardır. Yaptıkları işlerin sonuçlarını düşünerek temkinli adımlar attıkları görülmektedir. Bu varsayımların sonucunda iklimin insan davranışlarında ve karakterinde yarattığı değişiklikler, bulunulan iklim bölgelerine göre değiş̧iklik gösterdiği görülmektedir. İfade edilen bu iki iklim bölgesi insanların karakter, huy, ahlak ve yaşama şekillerinde ciddi farklılı̆̆ın ortaya çıkmasında etkili olmuştur (İbn Haldun, 2011:267).

İbn Haldun orta kuşakta yaşayan toplulukların, yaşadığı toplum özelliklerinin medeniyetlerin gelişimi noktasında önemli olduğunu ortaya koyar. $\mathrm{Bu}$ doğrultuda ortaya çıkan toplum özellikleriyle beraber medeniyetler, 1lıman iklimin olduğu yerlere ilerleme göstermektedir. İbn Haldun'a göre mutedil yani 1lıman iklim kuşağının sağladığı şartlardan dolayı orada yaşayan insanların yaşam şartları diğer iklim bölgelerine oranla mükemmel olarak nitelendirilmektedir. Yaşam koşullarının daha rahat olmasından kaynaklı birçok alanda gelişim gösterirler. Diğer toplumlara oranla toplumun bütün alanlarda daha ileri olmalarını sağlayan bir yarış süreci içinde olduklarından bahsedilmektedir (İbn Haldun, 2004:116).

Buna ek olarak çevre etkisinde oluşan bu topluluğun belli bir düzen içinde yaşamayı gerektirecek kurallarının olması gerektiğinden bahsetmektedir. Topluluk halinde yaşamanın doğal bir sonucu olarak kaos ve çatışmalar ortaya çıkmaktadır. Bu durumda topluma bir düzen getirmek ve insanların birbirlerine zulmetmelerine engel olmak için bir idareciye ihtiyaç duyarlar (İbn Haldun, 2004:267). İbn Haldun'a göre bir devleti kurmak ve devamlılığını sağlamak için idarecinin güçlü bir soy bağının olması gerektirmektedir. İbn Haldun bu durumu Asabiyet teorisi ile açıklamakta ve yönettiği toplumla arasında soy bağının olmadığı bir bireyin devleti yönetemeyeceğinden bahsetmektedir. Buna bağlı olarak oluşabilecek sorunlarla mücadele esnasında ortaya çıkan bir hasar devlete de sınırlı bir ömür biçilmesini sağlamıştır. Bu da Asabiyet teorisi kapsamında bu gibi yönetimlerin sürekliliğinin olamayacağı sonucunu ortaya koymaktadır (İbn Haldun, 2004:216-218).

\subsection{Montesquieu'ye Göre Çevresel Determinizm}

Charles-Louis de Secondat adıyla bilinen Montesquieu 18 Ocak 1689 y1lında Bordeaux'un bir beldesi olan la Brêde'de doğmuştur. Soylu bir ailede dünyaya gelen Montesquieu'nun tüm insanların kardeşçe yaşaması gerektiğini unutmasın diye dilenci bir vaftiz babası, ailesi tarafından seçilmiştir. O dönemde vaftiz babası vaftiz edilen çocuğun babasına eş değerde bir sınıfta olması gerekirdi. Katolik dinine uygun olmayan bu durum 18. yüzyıl içinde yaşayan Montesquieu'nun ve eserlerinin üzerinde hayli etkili olmuştur. Eserlerinde özgürlük, eşitlik, demokrasi gibi kavramların bulunmasında aynı zamanda Aydınlanma Çağıyla beraber etkili olan bu nosyonlar toplumun mutluluğu için gerekli bir ön koşuldur (Montesquieu, 2014:21-23). 
Aydınlanma Çağı, sosyolojinin gelişmesi adına önemli bir dönem olmuştur. Bu dönemde Montesquieu, Kanunların Ruhu kitabıyla kuvvetler ayrılığı kavramını ortaya koymuştur. Bu eserle dönemin Amerikan Anayasası'nı ve 1789-1799 yılları arasında gerçekleşen Fransız İhtilali'nin hazırlanılması ve yön verilmesi noktasında önemli bir dönüm noktası olarak görülmüsstür. Kanunların Ruhu eseri kendisinden önce kaleme alınan İran Mektupları eserini toplumsal ilişkileri çok boyutlu ele alarak sağlam bir mantaliteye oturtmaktadır. İran Mektupları bu önemli eserin bazı bölümlerine temel olmuştur. 1721 senesinde yazar ismi yazılmadan yayınlanan İran mektupları o dönem toplumda büyük bir yankı uyandırmıştır. Yankı uyandırmasının asıl sebebi kitabın ana karakteri olan İranlı gezgin Usbek ve Rica'nın mektuplaşmalarıyla o dönemin gelenekleri, kültürü ve demografik özelliklerinin bir roman havasında eleştirilmesiydi. Doğu insanı burada küçük görülmeye çalışılmasa dâhi Avrupa kültüründen farklı olduğu açık bir şekilde ortaya konulmuştur. Genel olarak oryantalist düşüncenin izlerini gördüğümüz eserdeki asıl amaç Doğu değildir. Bilakis Doğu bakış açısıyla 18. yüzyıl Fransa'sinı anlatmaktır (Durmaz, 2004:56-59).

Montesquieu, yaşadığı toplumu ve diğer toplumları analiz ederken Kanunların Ruhu kitabında o toplumların ne şekilde yönetilmesi gerektiğinden bahsetmiştir. Bununla birlikte toplumların pek çok şey tarafindan yönetildiğinden de bahseder. Toplumu bu noktada; ahlak, toplumsal kurallar, evrensel yasalar, örf ve adetler, kanunlar ve iklimin şekillendirdiğini ortaya koyar. Bunların hepsi de toplumun değerlerinin çerçevesini oluşturur. Bu noktada Montesquieu, Kanunların Ruhu kitabının temelini oluşturan İran mektupları kitabında yalnızca tarihi kaynakların ve hukuk kitaplarının mevcut toplumları anlamak için yeterli olmadığını, toplumun diğer bir belirleyicisi olan iklimin toplumun şekillenmesinde etkisinin olduğunu ortaya koymaktadır (Montesqueiu, 1963:15-17).

Montesquieu'nün çevresel determinizme bakış açısı İbn Haldun'un birinci Mukaddimesi'nin sonunda bahsedilen bakış açısıyla benzerlik göstermektedir. Hem biyolojik özellikler hem de iklim şartlarını ele alarak insanların doğa ile olan ilişkilerine değinmektedir (İbn-i Haldun, 2011:119). Montesquieu de Kanunların Ruhu kitabının ilk bölümlerinde ifade ettiği fiziki şartların ve iklimin, toplulukların gelişim ve değişimlerinde önemli roller oynamaktadır. Özellikler toplumsal düzeni sağlayan kanunlar üzerinde de ciddi bir etkiye sahiptir.

\subsubsection{Montesquieu'nun Çevresel Determinizm Kapsamında Toplum ve Yönetime Dair Teorisi}

Montesquieu'ye göre insanı yöneten birtakım şeyler vardır. Bunlar; din, yasalar, gelenekler, toplumun geçmiş kimliği, çevre vb.'dir. Toplumun belirleyicisi olan çevrenin en temel unsuru o toplumun yaşadığı iklimdir. İklim, toplumda bireylerin mizacını, ahlakını, bireyin topluma uyum derecesini belirler. İnsanı yöneten iklim, yönetimin doğasını oluşturur. Yönetimi oluşturan unsur da toplum yani insandır. İklim insan mizacını ve dolaylı olarak da yönetimi ve yasaları etkiler. Bu bakımdan ortak davranış şekillerine sahip olmalarını sağlayacak fizyolojik özellikleri kazandırır. İklimin ve yer şekillerinin etkilerinden kaynaklı olarak kazanılan fiziksel özellikler ve mizaç, farklı iklimlerde yaşayan insanlar açısından değişiklik gösterir. Yönetimin doğasını oluşturması bakımından farklı iklim bölgelerindeki toplumlar; farklı yasalarla, farklı yönetim şekilleriyle yönetilirler. Her toplumun özelliklerinin farklı olmasından kaynaklı olarak yönetimleri de kendilerine özgüdür (Althusser, 2005:70-71).

Toplumdaki düzeni sağlayan kanunlar insanların ve hayvanların kendi içlerindeki ilişkiye ve doğa ile olan uyumuna bağlı olarak gelişmektedir. Bu yüzden doğa ve toplum arasındaki ilişkiyi düzenleyen ilk kanun doğa kanunlarıdır. Doğa kanunları, doğa ile insan ilişkisini yönlendiren bir belirleyici olmakla birlikte; doğa ve insan varlığının başlangıcını oluşturur aynı zamanda devamını sağlar. Bu devamlılık önce doğa kanunlarıyla sonra insan kanunlarıyla gerçekleşir. Doğa kanunları insanların toplu halde yaşama istekleri noktasında belirleyicidir. $\mathrm{Bu}$ belirleyicilik zamanla toplu halde yaşayan insanların aralarındaki eşitsizliği ortaya çıkarır. Zamanla eşitsizlikler güç çatışmalarına ve nihayetinde savaşlara sebep olur. Bu noktada her toplum mevcut yapısına uygun kurallar ve kanunlar benimsemektedir. İnsan eliyle yapılan bu kanunlar doğa olaylarından etkilenen toplumların ilk kanunu olan doğa kanunlarını temel alarak düzenlenmektedir. Montesquieu doğa kanunlarının kapsamını belirleyen çevresel determinizme (belirlenimcilik) dikkat çekmektedir (Montesquieu, 2014:43-48)

$\mathrm{Bu}$ doğa kanunlarının sağlamış olduğu değişiklikler Montesquieu'ye göre soğuk iklimde yaşayanların vücudundaki liflerin gerginleşmesini sağlar. Liflerinin bu gerginlikten kaynaklı olarak güçlü oluşu hazmı zor olan yiyecekleri dâhi kolaylıkla sindirmelerini sağlamaktadır. Liflerin gerginliğinin diğer bir sonucu ise kanın kalbe akışını kolaylaştırmaktır. Kan akışını düzenleyen bu durum kalbin daha iyi işlemesine ve vücuttaki sıvıların daha dengeli olmasına sebep olur ve soğuğun etkisiyle bedenleri dinçleşir. Bundan ötürü soğuk bölgelerde yaşayan topluluklar genellikle kuvvetli olurlar. Kuvvetli olmalarının sonucu olarak da cesur kimseler olurlar, kendilerine güvenirler ve bu yüzden hileye başvurma gereksinimi duymazlar (Montesquieu, 1998:322). 
Sıcak iklimler bu durumun tam tersine liflerin ucunu esnekleştirir. $\mathrm{Bu}$ durum bu iklimlerde yaşayan toplulukların güçlerini ve esnekliklerini azaltmaktadır. Güçlerinin az olmasından dolayı çekingendirler. Bu sonuç geçmiş savaşlara bakılarak kuzey kesiminde yaşayanların güneyde yaşayanlardan daha cesur ve kuvvetli olmasından yola çıkılarak ortaya konmuştur. Ayrıca bu bölgenin insanlarının lif yapısındaki esneklik sonucu ağır yiyecekleri hazmetmeleri de zorlaşmaktadır (Montesquieu, 1998:322).

Sayılan bu farklılıklar dışında diğer bir farklılık ise iklimlere göre o bölgenin topluluklarının eğlenceye olan düşkünlükleridir. Montesquieu'nün İngiltere ve İtalya'da gitmiş olduğu operaları karşılaştırdığında görüyoruz ki her iki operada da aynı oyunlar aynı kişilerce oynanmış olsa dâhi biri sakin bir diğeri oldukça hareketli olan iki ayrı topluluk üzerinde farklı etki yaratılıyordu. Bunun sonucu olarak da soğuk bölgelerde yaşayanların eğlenmeye çok da düşkün olmadığı, 1lıman iklim yapısında yaşayanların bu duruma oranla biraz daha eğlenmeye ve sefaya düşkün olduğu, sıcak bölgelerde yaşayanların ise eğlenmeye olan düşkünlüklerinin çok fazla olduğu görülmektedir (Montesquieu, 1998:324).

$\mathrm{Bu}$ zevk ve sefaya düşkün olma durumlarında farklılık olduğu gibi acıya karşı dayanıkl1lıklarında da farklılıklar görülmektedir Sıcak iklim bölgelerinde, sıcaklık ciddi anlamda çok yüksek olduğundan insan bedeni halsiz düsser. $\mathrm{Bu}$ halsizlik ve yorgunluk hali bu bölgedeki insanların ruhlarına tesir etmektedir. Bu ruh hali de o bölgede yaşayanlarda ne bir istek ne bir çabalama hali ne de cesaret ve mertlik hali birakmaktadır. Bunun sonucu olarak da eylemlerinde pasifleştikleri görülmektedir. Pasif hallerinden mutlu olurlar. Mevcut mutlu durumlarını sarsmamak için de risk almadıkları görülür (Montesquieu, 1998:325).

Sıcak iklim insanlarının mevcut hava koşullarından kaynaklı olarak güçleri de azdır ve bir ceza durumu karşısında ağır işlere katlanırlar. Bu durumun doğal bir sonucu olarak bu iklim toplumlarında kölelik meşru bir durum olarak görülür. Bu durum iklimle beraber yasaların kötü olmasından da kaynaklıdır. Montesquieu'ya göre kötü yasalar tembel bir topluluk ortaya çıkarır. Tembel olmanın sonucu köle kavramını ortaya çıkarır (Aron, 2010:38-40). Burada Montesquieu ilk başta köleliğin zorunlu bir durum olmadığından bahsederken daha sonra yönetim ve iklim koşulunun bunu zorunlu hâle getirdiği tezini ortaya koyar. Aron da bu noktada Montesquieu'nün İklim Teorisi'ndeki çelişkiyi eleştirmektedir. Tam anlamıla iklimin asıl belirleyici unsur olmadığından söz etmektedir. Aron'a göre iklimin toplumsal anlamda belirleyiciliğinden ziyade etkileyici bir unsur olduğundan bahseder ve bu noktada Montesquieu'dan ayr1lır (Aron, 2010:41).

Montesquieu soğuk bölgelerde yaşayanların bedenlerinin iri olduğunu ve bedenlerinin iri olması dolayısıyla bu bölgedeki kişilerin güçlü olduklarını da gösterir. Bedenlerinin güçlü olması yanı sıra ruhları da bir o kadar güçlüdür. Güçlü bir yapıya sahip olan soğuk iklim insanları güçlerinden dolayı kendilerine güvenirler ve bu durumun sonucu olarak özgüvenlidirler (Montesquieu, 1998:322).

Montesquieu bu genellemeleri yaptıktan sonra birtakım çelişkilerinde mevcut olduğunu görmüştür. Bu çelişki Hintlilerin bazı geleneklerinin getirmiş olduğu davranışlarda görülmektedir. Geleneklerinden gelen bazı inanışları sergilerlerken kendilerini hiç çekinmeden ateşe attıklarını ve acı verici birtakım işkencelere dayanabildikleri ortaya çıkmıştır. $\mathrm{Bu}$ durum haliyle genel tezi çürütecek çelişkiler barındırmaktadır (Montesquieu, 1998:325).

Elde ettiği veriler sonucunda Montesquieu aslında yaptığı genellemeye etki edecek başka bir faktörün varlığından da bahsetmektedir. Gelişim özellikleri gösteremeyen bölgelerin insanlarının değişime açık, sağduyulu ve zeki ılıman iklim insanlarından çok bir yasa yapıcıya ihtiyaçlarının olduğunu ortaya koymuştur. Bu yasacının yönetimi hâli hazırda sahip olduğu sıcak iklimin verdiği rehavetten dolayı tembellik yapan halkı harekete geçirirken güçlerine güvenip kendi otoritesini korumaya çalışan soğuk iklim insanlarının davranışlarının kontrol altına alınmasını sağlar. Böylece gelenekler ve mevcut yasalar insanların mevcut kaderlerinde değişim sağlarlar. Bununla birlikte toplum düzeninde yalnızca kanunların etkili olmadığından, belirli sinırları olsa da kanun koyucunun etkisinin de olduğundan bahsetmektedir (Montesquieu, 1998:326-328).

\section{SONUÇ}

Coğrafya, çevre ve insan ilişkisini başta Dünya'nın yedi bölgeye ayrılması ile açıklamaya çalışmaktadır. Daha sonraları ise yer şekilleri, iklim koşulları, fiziki çevre gibi çevresel etkenleri temele alarak çevrenin insanla olan karşılıklı ilişkisini değerlendirmiş beşerî coğrafya ve fiziki coğrafya ekseninde incelemeler yapılmıştır. İbn Haldun 14. Yüzyılda Umran ilmi ve Asabiyet teorilerini merkeze alarak insan- çevre ilişkisine değinmiştir. Daha sonraları modern coğrafya teorisyenlerinden Kant, Humboldt, Ritter, Darwin ve Ratzel'in insan-yer ilişkisine dair araştırmaları çevresel determinizmin gelişmesine katkı sağlamıştır. Darwin, Humboldt ve Ritter'den sonraki dönemde yayınladığı Türlerin Kökeni kitabıyla ciddi yankı uyandırmıştır. Çevresel 
determinizme kuramsal anlamda katkısı olan Darwin'in, canlıların mevcut doğal şartlara uyum sağlayabilmesi için birtakım zorunlu değişiklikler geçirdiğinden bahsetmektedir. Doğaya uyum sağlayan canlılar, doğal koşulların farklı olmasından kaynaklı olarak farklı özelliklere sahip canlıların ortaya çıktığından söz etmektedir. Darwin'in teorilerinden etkilenen Ratzel, çevreye uyum sağlamanın doğanın ortaya çıkaracağı engelleri aşmakta kolaylık sağlayacağını ortaya koymuştur.

18. yüzyılda çevresel determinizmi devlet yönetimi ve yasalar açından ele alan Montesquieu'da birçok bakımdan İbn Haldun ile benzerlik göstermektedir. Bu noktada İbn-i Haldun ve Montesquieu'nun teorileri çerçevesinde çevresel determinizmin insan ve toplum üzerindeki belirleyiciliği tartışılmıştır. Montesquieu ve İbn-i Haldun farklı dönemlerde yaşamalarına rağmen doğanın, insan üzerindeki etkisini ele almaları noktasında ortak bir bakış açısına sahip oldukları görülmektedir. Çevrenin ve buna bağlı çevresel koşulların toplumdaki bireylerin yaşam şekillerini, kültürlerini ve toplumun düzenini sağlayan toplumsal kuralları etkilediğini ortaya koymuşlardır. Farklı toplumlarda yaşayan bireylerin, karakter ve mizaç özellikleri toplumsal kurallar oluşturma noktasında belirleyici olmaktadır.

İbn-i Haldun Dünya'yı yedi iklim bölgesine ayırmıştır. Kuzeyde bulunan bölgeler soğuk, güneyde bulunan bölgeler sıcak ve orta kuşakta bulunan bölgeleri 1lıman iklim bölgesi olarak ayırmıştır. İklimlerine göre insanların fiziksel, ahlaki, karakteristik ve mizaç özellikleri üzerindeki etkilerini ele alarak yedi iklim teorisini ortaya koymuştur. Sıcak iklimde yaşayan insanların tez canlı olduğundan, zevk ve sefa düşkünlüklerinden bahsetmektedir. $\mathrm{Bu}$ zevk ve sefaya düşkünlüklerinden dolayı zekâlarının da pek gelişmediğinden bahsetmektedir. Soğuk iklimde yaşayan insanların daha dinç yapılarının olduğundan bahsetmektedir. Bununla beraber sorumluluk sahibi oluşları, olasılıkları önceden düşünerek temkinli hareket etmeleri ön plana çıan özelliklerindendir. Ilıman iklim bölgesi ise insanların her yönden gelişiminin en iyi şekilde olmasını sağlayan çevresel şartlara sahiptir. Soğuk ve sıcak iklim bölgelerinde görülen aşırılıklar bu bölgenin 1lıman iklim yapısından kaynaklı olarak görülmemektedir. Ayrıca bu bölgede yaşayan insanlar toplumsal gelişim açısından bir yarış içerisindedir. Bu noktada bu bölgelerde yaşayan insanların belli bir düzen içerisinde yaşamalarını sağlayan bir hükümdara ve kanuna ihtiyaç duyduklarından bahsedilmektedir.

Montesquieu ise çevre-doğa ilişkisini kanunlar çerçevesinde ele almaktadır. Toplumsal olayların gelişim süreçlerini gözlemleyerek insanların yaşayış şekilleri, yaşanan bölgenin iklim koşulları ve fiziki şartları determinist bir bakış açısıyla ele alır. Sıcak bölgede yaşayanlar iklimin etkisiyle halsiz ve yorgun bir ruh haline sahiplerdir aynı zamanda güçleri de azdır. Ilıman bölgede yaşayanlar zeki, sağduyulu ve gelişime açık kimselerdir. Soğuk bölge yaşayan insanların bedenlerinin iri olduğunu burada yaşayanların ise güçlü bireyler olduğunu ifade etmektedir. Bu görüşü ortaya koyarken farklı bir belirleyicinin söz konu olduğundan da bahseder. Bunun toplumsal düzeni sağlayan kanunlar, kanun koyucular ve gelenekler olduğunu ortaya koymuştur. Kanun ve kanun koyucuların toplumun değişim ve gelişimi üzerinde etkisinin olduğundan bahsetmektedir. Çevresel determinizmin belirleyicisi olduğu toplumlarda oluşan bazı karakteristik özellikler ve alışkanlıklar ortaya çıkmaktadır. Bu durum bölgedeki insanların özelliklerine uygun farklı yasalarla yönetilmeleri konusunda belirleyici olmuştur

Sonuç olarak İbn Haldun'un ve Montestequieu'nün teorileri çıkarımları bakımından birbirinde farklı olsa da ikisinin de konuyu ele aldığ nokta ve yöntem benzerdir. İkisi de siyasetle ilgilenmiş olmalarından kaynaklı olarak ele aldıkları toplumların yönetimine dair görüşler ortaya koymuşlardır. İbn Haldun'un Orta Asya'da yaşaması ve Montesquieu'nün de Avrupa'da yaşamış olması bulundukları toplumdan etkilenmelerini sağlamıştır. Benzer bir diğer noktaları ise toplumun birçok unsur tarafından yönetilebileceğidir. Bu unsurlar; iklim, ahlâk, kanun, din ve geleneklerdir. Canlıların düzenlerini sağlamak adına doğa kanunları bir temel niteliğindeydi. İnsanların topluluklar halinde yaşamalarıyla ortaya çıkan çatışmalar toplumu yönetmek için bir hükümdarın ve kanunların varlığını gerekli k1lıyordu.

İbn Haldun ve Montesquieu da bu noktada toplumun belirleyicisi olan çevrenin aynı zamanda kanunların ve toplumsal düzenin de belirleyicisi olduğu düşüncesini ortaya koymuştur. Fakat İbn Haldun'a göre devlet kurmak ve yönetmek güçlü bir soy bağı gerektirmektedir. Soy bağının olmadığı bir bireyin devleti yönetemeyeceğinden bahseder. Bu noktada devletin sınırlı bir ömre sahip olduğunu da belirtmiştir. Bu da Asabiyet teorisi kapsamındaki yönetimlerin sürekliliğinin olmayacağı sonucunu ortaya çıkarmaktadır. Montesquieu ise devleti oluşturan en temel şeyin kanunlar olduğundan bahseder. Her toplumun kendi yaşam koşullarına, toplum kimliğine ve iklimin etkilediği özelliklere uygun kanunlar yapığını ortaya koymuştur. Devleti yalnız kanunların değil, yasa koyucuların da belirli çerçevedeki yetkilerine dayandırmaktadır. İki kuram da incelendiğinde farklı görüşlere ve farklı yönetim anlayışlarına sahip olsalar da ikisi de devletin varlığının gerekliliği noktasında ortak görüş ortaya koymuştur. Farklı toplumlarda yaşamalarına karşın devletin ve içinde yaşayan bireylerin özelliklerinin belirleyicisi olarak çevreyi gördükleri sonucuna varılmaktadır. 
Ortaya çıkan bu tez ve görüşleri ayrıntılı analiz ettiğimizde çevresel determizm İbn Haldun'un bölgesel coğrafya eksenindeki görüşleri merkezinde birçok bakış açısıyla zengin bir içerik kazanmıştır. Ondan 400 sene sonra Montesquieu da bu konu merkezinde yasalar ve yönetim çerçevesinde görüşler ortaya koymuştur. Klasik dönem sonrasında ise Kant, Humboldt, Ritter ve Ratzel modern coğrafyanın temeli oluşturmuşlardır. Ritter ve Humboldt'un ölümünden sonra Darwinin görüşleri ortaya çıkmıştır. Darwin'in teorileri birçok coğrafyacıyı etkilediği gibi Ratzel'i de etkilemiştir. F.Ratzel de Darwin teorilerinden etkilenerek siyasi coğrafyanın temelini oluşturmuştur. F.Ratzel'in siyasi coğrafya üzerine ortaya koyduğu düşünceleri zamanla Semple ve Huntington'1 da etkilemiştir. Çevresel determinizmi ve bunun temelini oluşturan siyasi coğrafyayı çeşitli açılardan ele alan belirlenimciler toplumun düzenini ve insanların birtakım özelliklerinin belirleyicisi olan çevreyi merkeze alarak çalışmalar yapmışlardır.

$\mathrm{Bu}$ çalışmada çevresel determinizmin yapı taşını oluşturan biyolojik determinizmden ve daha sonra çevresel determinizm kuramı çerçevesinde ortaya çıkan görüşler ele alınmıştır. Devamında görüşlerin bazı noktalarda kendi içinde tezatlıklar oluşturduğu görülmüştür. Bu durumu eleştirenlerin görüşleri analiz edilmiştir. Çevresel determinizm kendisinden sonra gelişen görüşler ele alındığında toplumu sadece doğal koşulların değil siyasi, ekonomik, kültürel pek çok faktörün etkilediği görülmüştür. Bu durum karşısında çevresel determinizmin ortaya koyduğu teorinin toplumların gelişmesiyle, toplumun belirleyicisi olması noktasında tek başına çevre faktörünün ele alınmasının yetersiz olacağı sonucu ortaya çıkmıştır. Çevresel determinizm tüm bu görüşlerin ortaya çıkmasında bir temel görevi gördüğü ve toplum düzeninin sağlanmasında birçok alanda önemli çalışmaların ortaya çıkmasında büyük payı vardır.

\section{KAYNAKÇA}

ACEMOĞLU, Daron ve ROBİNSON, James A. (2013), Ulusların Düşüşü: Güç, Zenginlik ve Yoksulluğun Kökenleri (Çev. Faruk Rasim Velioğlu), Doğan Kitap Yayınları, İstanbul.

ALTHUSSER, Louis (2005), Montesquieu: Siyaset ve Tarih (Çev. A. Tümertekin), İthaki Yayınları, İstanbul.

ARI, Y1lmaz (2017), “Çevresel Determinizmden Politik Ekolojiye: Son 100 Yllda Dünya'da ve Türkiye'de İnsan - Çevre Coğrafyasındaki Yaklaşımlar”, Doğu Coğrafya Dergisi, S.22(37), ss.1-34.

ARON, Raymond (2010), Sosyolojik Düşüncenin Evreleri, Kırmızı Yayınları, İstanbul, 8. Bask1.

DARWIN, Charles (2013), Türlerin Kökeni (Çev. Öner Ünalan), Evrensel Basım Yayın, İstanbul.

DİAMOND, Jared (2010), Tüfek, Mikrop ve Çelik (Çev. Ülker İnce), TÜBİTAK Yayınları, Ankara.

DURMAZ, Kaan (2004), Doğu - Batı İkilemine Dört Bakış, Kültür Yayınları, İstanbul.

İBN-İ HALDUN (2004), Mukaddime (Çev. H. Kendir), Yeni Şafak Yayını, Ankara.

İBN-İ HALDUN (2011), Mukaddime (Çev. S. Uludağ), Dergah Yayınları, İstanbul.

KUTLUER, İlhan (1994), TDV İslam Ansiklopedisi, Türk Diyanet Vakfı Yayınevi, Ankara, C.9.

LACOSTE, Y. (2012), İbni Haldun: Tarih Biliminin Doğuşu (Çev. M. Sert), Ayrıntı Yayınları, İstanbul.

MONTESQUIEUU, Charles (1963), İran Mektupları (Çev. Muhiddin Göklü), Hüsnütabiat Matbası, İstanbul.

MONTESQUiEU, Charles (1998), Kanunların Ruhu Üzerine (Çev. F. Baldaş), Toplumsal Dönüşüm Yayınları, İstanbul.

MONTESQUIEU, Charles (2014), Kanunların Ruhu Üzerine (Çev. F. Baldaş), Hiperlink Yayınları, İstanbul.

ÖZGEN, Nurettin ve KARADOĞAN, Sabri (2016), Fiziki Coğrafyada Araştırma Yöntemleri ve Teknikleri, Pegem Akademi Yayınları, Ankara.

ŞERİATİ, Ali (2017), İnsanın Dört Zindanı, Fecr Yayınları, Ankara.

https://tr.wikipedia.org/wiki/Determinizm (Erişim Tarihi: 17.04.2020).

https://tr.wikipedia.org/wiki/Doğal_çevre (Erişim Tarihi: 17.04.2020). 